\title{
THE INFLUENCE OF TEAM ASSISTED INDIVIDUALIZATION (TAI) ON TEAM LEARNING MODEL OF GEOGRAPHIC JUNIOR HIGH SCHOOL IN LUMAJANG
}

\author{
Bejo Apriyanto ${ }^{1}$, Elan Artono Nurdin ${ }^{2}$, Fahmi Arif Kurnianto ${ }^{3}$, Fahrudi Ahwan \\ Ikhsan $^{4}$ \\ ${ }^{1234}$ Departement of Geography Education, University of Jember, Indonesia \\ E-mail: apriyanto.bejo@unej.ac.id \\ DOI: $10.19184 /$ geosi.v2i1.7527
}

Article History: Received Date $8^{\text {th }}$ February 2018, Received Revised $22^{\text {th }}$ March 2018, Accepted Date $28^{\text {th }}$ April 2018, Published Date $30^{\text {th }}$ April 2018

\begin{abstract}
Selection of the right learning model will increase the chances of achieving student learning success. The choice of learning model should pay attention to students' ability which is generally not the same among students one to another. The main factors are the various intelligence and student backgrounds. In addition, the absorptive capacity of the subject matter between students with one student is not the same so that affect learning outcomes achieved. Therefore, teachers need alternative learning model to overcome the diversity of student characteristics, one of them is with individual learning. However, the large number of students in the classroom and the various shortcomings in individual learning such as the effectiveness of learning, time, effort, and curriculum demands, as well as other obstacles, then individual learning is very unlikely to be implemented. An alternative that teachers can do is through the use of learning models that lead to programmed individual learning. The model of learning in accordance with the problem is Model Team Assisted Individualization (TAI). The TAI model is designed as a learning model that combines individual learning with cooperative learning. With the TAI model, the weaknesses that exist in individual learning and on cooperative learning can be minimized with the advantages that exist in both. This study aims to determine the effect of the use of TAI Model on the results of IPS geography learning. This research includes quasi experiment type, using Pretest-posttest Control Group Design design. The subjects consisted of one experimental class and one control class, grade VII student SMPN 4 Lumajang. The research instrument is a test consisting of prates and pascates. The data analysis technique uses t-test with SPSS 16.00 for Windows. The result of data analysis shows that the learning result of IPS geography of students using TAI model is better than students who do not use TAI Model. Thus
\end{abstract}


it can be argued that the use of TAI model influences the learning outcomes Geography IPS Geography students proposed for teachers in the field of study Geography is to make the Model TAI as an alternative model of learning to improve student learning outcomes. Suggestions for further research are piloting the TAI Model on different materials and levels of higher classes or schools, as well as combining with more varied learning media so as to show a great influence on student learning outcomes and gain greater benefits from the TAI Model.

Key Words: Model Team Assisted Individualization (TAI), Geography Learning Result

\section{INTRODUCTION}

The learning process is very instrumental in the success of student learning. One of the success of the learning process is the selection of learning models. Selection of the right learning model will increase the chances of achieving learning success. The choice of learning model should consider the characteristics of students who generally have unequal differences in ability and knowledge. Slavin (2008: 7) suggests "students enter into classes with very different backgrounds in skills and knowledge". This of course will affect in terms of absorption and the level of students' understanding of the given material will not be the same. Djamarah (2012: 74) states "Factor intelligence affects the ability of students to absorb the lesson material provided by the teacher". It is therefore important for all teachers to be aware of this so that a teacher who is directly involved in the teaching-learning process in the classroom has the idea of how to deal with such student characteristics.

The very effective learning model used by teachers in the classroom with the number of students is a lot of cooperative learning model Team Assisted Individualization (TAI). Slavin (2008: 189) suggests "The TAI model was initiated as an effort to design an individual form of teaching that can solve problems that make individual teaching methods ineffective."

The TAI model can be used as an alternative for teachers to conduct individualized learning programmatically, because the learning in this model combines individual teaching with cooperative teaching so that learning success can be achieved jointly by all individuals in each group for one class. In addition 
TAI model can overcome the problems that often arise in cooperative learning in general is the diffusion of responsibilities for some members of the group.

Learning is essentially a change in a person's behavior after a process. Learning outcomes according to Sudjana (2009: 3) is "The results obtained in the form of impressions that result in changes in the individual as a result of activity in learning. Changes in these behaviors are indicators that serve as guidelines for knowing individual progress in everything that is gained in school ". While the results of IPS geography learning is the result obtained by students after following IPS Geography lesson. The result of learning in this research is emphasized on cognitive aspect. Bloom in Sudjana (2009: 20) states that the cognitive domain is divided into six domains that include recall, understanding, application, analysis, synthesis, and evaluation.

Learning is essentially a change of self / behavior of a person after experiencing the learning process. This is in line with the opinion of Rusyan et al. (1989: 8) "Learning in the broad sense is a process of behavior change expressed in the form of mastery, use, and assessment of attitudes and values, basic knowledge and skills contained in various fields study or more extensively in various aspects of life ".

The weaknesses of cooperative learning in Team Assisted Individualization (TAI) models can be minimized by providing different material units to each group member according to their ability in the Pleacement test step and the second is the group reward based on the score of each individual in the group score and recognition). Thus in Team Assisted Individualization Model (TAI) can eliminate the possibilities of potential barriers that often occur in cooperative learning in general. This is part of the co-operative learning of Team Assisted Individualization (TAI) model.

In cooperative learning the role of the teacher is as a facilitator and moderator who essentially convey the subject matter and provide guidance to the students in the learning process. Thus the teacher should be ready to guide each individual different, both from the level of intelligence, attitudes, and other characteristics of students. 


\section{METHODS}

This study aims to determine the effect of cooperative learning Team Assisted Individualization (TAI) model of geography learning outcomes. Based on the objectives formulated, then this research using quasi experiment design (quasi experiment). The design used in this research is Pretest-posttest Control Group Design where the research subject consists of experimental class and control class. The experimental class was given treatment in the form of cooperative learning model of Team Assisted Individualization (TAI), while control class as comparison was not treated by Team Assisted Individualization (TAI) model.

\section{RESULTS AND DISCUSSION}

1. Results

Based on the results of data analysis can be proposed research findings that model Teaching Assisted Individualization team influence the learning outcomes geography IPS. Students whose learning process using Team Assisted Individualization model get better learning outcomes than students whose learning process does not use Team Assisted Individualization model.

Based on the results of analysis that has been described earlier can ditemukaan that the use of Team Assisted Individualization Model can help improve the learning outcomes Geography IPS geography class VII SMP Negeri 4 Lumajang on the topic Hidrosphere so as to obtain better learning outcomes. Classes that the learning process using the TAI Model obtain higher average learning outcomes than those that do not use the TAI Model.

The use of TAI model has an effect on the learning result because the elements in the TAI program are able to give great benefit to the students during the learning process. All elements of TAI consisting of team, placement test, teaching group, student creative, team study, whole class unit, and Team Score and Team Recognition appear to influence student activities during the learning process.

At the stage of formation of heterogeneous learning groups (teams) to educate students not to discriminate both academic and gender. Initially, high- 
ability students are not familiar with low-skilled students, whereas low-ability students exhibit a reluctance to join those with high ability. This is indicated by the complaints of some students at the beginning of the group division, some students would not even move to the seat, and others were screaming because they did not fit in with a group friend. But in the next few minutes they got used to it and at the next meeting there was no complaint as before.

\section{Discussion}

The existence of a placement test that is not only based on the value of previous material is useful in determining individual guidance to students who are less able to understand the material being studied. With this placement test teachers can find out which students need a lot of help or guidance during their studies. In addition, teachers can also know which students are considered to provide assistance to their friends and do guidance in team study.

During Teaching Group implementation, students enthusiastically pay attention to what the teacher is saying, because in this Teaching Group the teacher first conveys the purpose of each learning step from team to stage Team Score and Team Recognition. At first the students did not want to pay attention to the teacher even many who crowded to make noise in the classroom. But when the teacher gives information that each individual gets individual assignments, scores, and tests at the end of the meeting, students slowly begin to show attention. So when the teacher delivers the outline of the material, students carefully consider the teacher's explanation.

Individual assignments in student creative encourage students to take responsibility for each task and not assign responsibility to other members because each student gets the same task with different material units, and the group score is based on the individual score earned on the task- tasks and individual tests, so that each student feels the burden and responsibility of each to succeed. Initially some students with below average ability were reluctant to work on individual material units. 


\section{CONCLUSION}

Based on the results of data analysis and discussion, it can be concluded that the use of Team Assisted Individualization learning model influences the learning outcomes of IPS Geography of VII grade students of SMP Negeri 3 Lumajang on Hydrosphere topic. The average classroom learning outcomes using Team Assisted Individualization model are higher than those that do not use Team Assisted Individualization

\section{REFERENCES}

Awang, H. \& Ramly, I. 2008. Creative Thinking Skill Approach Through Problem Based Learning: Pedagogy and Practice in the Engineering Clasroom. International Journal of Human and Social Sciences, 3 (1):106-109.

Bilgin, I., Senocak, E., \& Sozbilir, M. 2009. The Effects of Problem Based Learning Instruction on University Students Performance of Conceptual and Quantitative Problem in Gas Concepts. Eurasia Journal of Mathematics, Science \& Technology Education, 5 (2): 153-164.

Bowe, B., Flynn, C, Howard, R., \& Daly, S. 2003. Teaching Physics to Engineering Students Using Problem Based Learning. International Journal of Engineering Education, 19 (5): 742-746.

Daldjoeni. 1982. Pengantar Geografi. Bandung: Alumni Bandung.

Dasna, I Wayan.2005.Penggunaan Model Problem-Based Learning dan Kooperatif Learning untuk Meningkatkan Kualitas Proses dan Hasil Belajar Kuliah Metodelogi Penelitian. Malang: Lembaga Penelitian UM.

Dahar, Ratna Willis. 1996. Teori-teori Belajar. Jakarta: Erlangga

Demirel, M. \& Arslan, B. 2010. The Effects Of Problem Based Learning On Achievement, Attitude, Metacognitive Awareness and Motivation. Journal of Education. 38 (1): 55-66 